\title{
Kajian tingkat pendidikan ibu, besaran pendapatan rumah tangga dan praktek seputar asuh balita di antara rumah tangga anak balita stunting di Kabupaten Manggarai
}

\section{A study of maternal education level, household income and practice around infant and young child feeding practice among households with stunted children in Manggarai Regency}

\author{
Charles Conrad Rambung \\ a Badan Perencanaan Pembangunan Penelitian dan Pengembangan Daerah \\ Provinsi Nusa Tenggara Timur \\ E-mail: charles.conrad.rambung@gmail.com
}

Naskah Diterima : 14 Desember 2019; Di-review : 22 Desember 2019; Dimuat: 30 Desember 2019

DOI :

Copyright OFLOBAMORA 2019

\begin{abstract}
Stunting reflects chronic undernutrition during the most critical periods of growth and development in early life. A thorough effort is required to support stunting situation analysis in Manggarai Regency. Almost $43.3 \%$ of the children under five years of age are stunted in Manggarai Regency. Understanding the factors that contribute to high prevalence of stunting is important to prioritising efforts in battling stunting in the area.

This study examines the maternal and household determinants of stunting on infant and young child feeding practicesusing data from a larger study survey on families with stunted children in 2019 in Manggarai Regency.

We conducted a quantitative research study with a cross-sectional design, involving 78 housholdsin Waebelang village, Kecamatan Ruteng, Manggarai Regency.The mothers were selected using purposive sampling method. Respondents were inteviewed using a semistructured questionnaire on infant and young child feeding practicesgenerated in KoboToolbox application.The presence of association of different variables with perceptions and practice around infant and young child feeding practice was analysed statistically usin SPSS software package with the P value for statistical significance being set at $<0.05$. Pearson's Chi Square was used to test significance and associations between categorical variables. Results show that

Results show that there was a significant association between mother education and knowing the importance of exclusive breastfeeding and complementary foods for infants ( $p=0.011)$; there was a significant association between mother education and describing the correct various semi-solid food for infants ( $p=0.047)$; there was a significant association between mother education and knowing the age for introducing complementary foods for infants (0.036). This study also revealed the existence of significant association between household income and the importance of various protein sources for infants 6-23 months $(p=0.048)$.
\end{abstract}

Keywords : Stunting children; Mother education level; Manggarai Regency; Stunted children prevalensi; Health promotion.

\section{Abstrak}

Stunting merefleksikan situasi kronis kurang nutrisi pada periode pertumbuhan dan perkembangan yang paling kritis pada awal kehidupan. Untuk mendukung analisis situasi yang lebih detil, perlu dilakukan usaha-usaha yang mendukung pemahaman yang utuh akan situasi stunting di kabupaten Manggarai. Proporsi balita yang mengalami stunting di kabupaten 
ini mencapai $43,3 \%$. Memahami secara baik berbagai faktor yang ikut berkontribusi terhadap tingginya prevalensi stunting di kabupaten ini justru penting untuk menetapkan kegiatan prioritas menekan stunting.

Kajian ini berusaha memahami hubungan karakteristik ibu dan rumah tangga sebagai determinan stunting terhadap praktek seputar asuh balita menggunakan data survey tahun 2019 terhadap rumah tangga yang memiliki anak stunting di Kabupaten Manggarai. Ini adalah studi kuantitatif dengan rancangan studi potong lintang, melibatkan 78 rumah tangga di Desa Waebelang, Kecamatan Ruteng, Kabupaten Manggarai. Ibu dari rumah tangga dipilih berdasarkan metode purposive sampling. Panduan wawancara terstrukutur yang mencakup persepsi dan praktek seputar asuh bayi dan balita menggunakan aplikasi KoboToolbox. Hubungan dari berbagai variabel terhadap persepsi dan praktek seputar asuh bayi dan balita dianalisa secara statistik menggunakan program SPSS dengan signifikasi nilai $\mathrm{p}<0,05$. Pearson's Chi Square digunakan untuk menguji signifikansi dan asosiasi antara variabel kategorikal.

Studi ini menunjukkan bahwa ada hubungan antara tingkat pendidikan ibu dengan pemahaman tentang pentingnya ASI dan makanan pendamping ASI $(\mathrm{p}=0,011)$; ada hubungan antara tingkat pendidikan ibu dengan pemahaman tentang jenis makanan semi solid yang dapat diperkenalkan kepada bayi ( $\mathrm{p}=0,047)$; ada hubungan antara tingkat pendidikan ibu dengan pemahaman tentang usia bayi yang tepat untuk diperkenalkan dengan makanan tambahan $(p=0,036)$. Studi ini juga menunjukan bahwa ada hubungan antara besaran pendapatan rumah tangga dengan pemahaman tentang pentingnya sumber protein yang bervariasi bagi bayi umur 6-23 bulan $(\mathrm{p}=0,048)$.

Kata Kunci : Stunting; Tingkat pendidikan ibu; Kabupaten Manggarai; Prevalensi stunting; Promosi kesehatan.

\section{Pendahuluan}

Stunting atau sering disebut kerdil atau pendek adalah kondisi gagal tumbuh pada anak berusia di bawah lima tahun (balita) akibat kekurangan gizi kronis dan infeksi berulang terutama dalam 1.000 Hari Pertama Kehidupan (HPK), yaitu dari janin hingga anak berusia 23 bulan. Anak tergolong stunting apabila panjang atau tinggi badannya berada di bawah minus dua standar deviasi panjang atau tinggi anak seumurnya dan karena akibat yang ditimbulkan cukup luas, maka stunting merupakan prediktor buruknya kualitas suber daya manusia (de Onis dan Branca, 2016).

Banyak faktor yang menyebabkan tingginya kejadian stunting pada balita di suatu wilayah. Salah satu determinan stunting termasuk pengetahuan ibu yang kurang dan pola asuh yang salah (Habimana \& Biracyaza, 2019; Poel, Hosseinpoor, Speybroeck, Ourti, \& Vega, 2008; Semba et al., 2008). Studi yang lain juga menunjukan bahwa faktor sosio-ekonomi keluarga terutama tingkat pendapatan turut berkontribusi terhadap tinggi angka balita stunting di suatu area (Case, Lubotsky, \& Paxson, 2002; Fink et al., 2017; Jurkowski et al., 2013; Lloyd et al., 2018; Mendez et al., 2016; Monteiro et al., 2010; Schmeer, 2010; Seguin, Xu, Potvin, Zunzunegui, \& Frohlich, 2003; Sharaf, Mansour, \& Rashad, 2019; Stobaugh et al., 2018) selain menyangkut keragaman nutrisi (Sunguya et al., 2014; Wang et al., 2017). Namun apakah faktor-faktor ini turut berkontribusi terhadap tingginya angka jumlah balita stunting di wilayah Kabupaten Manggarai belum diketahui dengan pasti. Padahal, tahun 2013, Kabupaten Manggarai mencatat proporsi jumlah balita stunting mencapai $43,3 \%$ jauh di atas rata-rata nasional yang 30,8\% (Stobaugh et al., 2018)

Dalam konteks aksi konvergensi melawan stunting, perlu dilakukan usaha-usaha yang mendukung pemahaman yang utuh akan situasi stunting di wilayah Kabupaten Manggarai. Strategi promosi kesehatan yang tepat sasar dan terobosan kebijakan diperlukan untuk mendukung reduksi angka stunting di wilayah Kabupaten Manggarai.

Studi ini dimaksud terutama untuk memastikan adanya hubungan antara tingkat pendidikan ibu, besaran pendapatan rumah tangga, dan praktek seputar asuh balita di antara rumah tangga yang memiliki anak balita stunting di Kabupaten Manggarai untuk memperkaya analisis situasi stunting di daerah tersebut dari aspek kuantitatif.

\section{Metode}

Studi ini adalah bagian kecil dari sebuah studi yang lebih besar tentang "Balita stunting: kajian terhadap pengetahuan (knowledge), sikap (attitude), dan praktek (practice) di antara rumah tangga sasaran program aksi konvergensi penanganan stunting Pemerintah Provinsi NTT" pada tahun 2019 dan menggunakan data kuantitatif yang diperoleh dari peneltian itu.

\subsection{Rancangan Studi}

Penelitian ini adalah penelitian kuantitatif dengan pendekatan studi menggunakan rancangan potong lintang. Data dikumpulkan pada satu titik waktu (one time point). Responden bersifat sukarela dan dijaga agar anonim dan diwawancarai secara langsung (face to face) menggunakan panduan wawancara terstruktur.

Teknik pengambilan sampel adalah secara purposif dengan memilih orang tua (ibu/wanita) dari rumah tangga anak balita stunting di desa WaeBelang, Kecamatan Ruteng, Kabupaten Manggarai.

\subsection{Partisipan}

Rumah tangga dari anak balita stunting dipilih secara purposif dari daftar menurut pencatatan ePPBGM tahun 2018 yang diperoleh dari Dinas Kesehatan Provinsi, memenuhi kriteria inklusi 
(tinggal di keempat desa target, usia 15-49 thn, memiliki anak balita di rumahnya), bersedia untuk diwawancara, dan menandatangani lembar persetujuan (informed consent).

Partisipan adalah wanita yang menjadi ibu atau pengasuh dan yang tinggal dengan anak yang dinyatakan stunting dengan asumsi bahwa partisipan bertanggung jawab menyiapkan asuhan bagi balita dimaksud.

\subsection{Prosedur}

Saat eligibilitas partisipan terkonfirmasi, partisipan akan langsung diberi penjelasan tentang tujuan studi dan jenis data yang dikumpulkan darinya. Partisipan akan ditanyai kesediaannya untuk berpartisipasi dalam studi. Segera setelah persetujuan diberikan, partisipan diwawancara di rumahnya.

Panduan wawancara terstruktur menggunakan kuesionar yang diadopsi dari kuesioner standar (Nutrition related KAP model questionnaires) yang dikembangkan oleh Food and Agriculture Organization-United Nations (FAO-UN). Berbagai penyesuaian dilakukan agar sesuai dengan konteks masyarakat yang akan diwawancarai.

Wawancara dibatasi berlangsung 60-90 menit agar tidak menyita waktu kerja partisipan atau waktu berkumpul dengan keluarga. Setiap hasil wawancara direkam secara digital menggunakan aplikasi KoboToolbox namun semua partisipan diberitahu bahwa percakapan akan direkam menggukan aplikasi dimaksud. Partisipan bersifat sukarela. Partisipan menerima sejumlah uang kas sebagai pengganti waktunya.

Kusioner terdiri dari beberapa kelompok pertanyaan yang relevan dengan studi ini meliputi 1) informasi umum dan informasi pendukung; 2) persepsi dan praktek seputar asuh bayi dan balita. Panduan pertanyaan telah terlebih dahulu diujicobakan dan diperbaiki sebelum digunakan untuk pengambilan data.

\subsection{Analisis kuantitatif}

Semua data yang dikumpulkan kemudian diberi kode sebelum data dimasukan ke dalam komputer sebagai variabel. Program SPSS versi 17.0 digunakan dalam proses entry data dan analisis. Statistik deskriptif dikerjakan untuk mendapatkan gambaran umum dan karakteristik data. Chi square tes dikerjakan untuk menilai adanya hubungan antara variabel dengan nilai signifikansi ditetapkan $\mathrm{p}<0.05$. Variabel bebas (independent variables) adalah tingkat pendidikan ibu dan besaran pendapatan rumah tangga. Tingkat pendidikan diukur berdasarkan jenjang pendidikan yang diselesaikan oleh ibu. Besaran pendapatan ditetapkan berdasarkan besaran rata-rata penghasilan yang diperoleh oleh rumah tangga setiap bulannnya.Variabel tergantung (dependent variables) adalah praktek seputar asuh balita di dalam rumah tangga.

\section{Hasil dan Pembahasan}

\subsection{Partisipan}

Sejumlah 78 orang berpartisipasi dalam studi ini. Secara umum, lebih dari $80 \%$ responden yang diwawancarai berusia di bawah 40 tahun dan separuhnya berada pada usia produktif. Ada $60 \%$ responden yang sedang hamil dan/atau sedang dalam periode menyusui bayi. Secara keseluruhan, lebih dari $80 \%$ responden yang diwawancarai tinggal di rumah sendiri/milik keluarga. Menariknya, kurang dari $50 \%$ responden wanita telah tamat pendidikan SMP. Detail mengenai partisipan tersaji pada Tabel 1 seperti berikut ini.

Tabel 1. Karakteristik responden

\begin{tabular}{|c|c|c|}
\hline Karakteristik & $\mathrm{N}$ & $\begin{array}{c}\text { Persentase } \\
(\%)\end{array}$ \\
\hline \multicolumn{3}{|l|}{ Status kehamilan } \\
\hline $\begin{array}{r}\text { Sedang hamil/ } \\
\text { menyusui }\end{array}$ & 31 & 39.7 \\
\hline $\begin{array}{r}\text { Tidak sedang hamil/ } \\
\text { menyusi }\end{array}$ & 47 & 60.3 \\
\hline \multicolumn{3}{|l|}{ Usia } \\
\hline $15-19$ thn & 0 & 0 \\
\hline $20-29$ thn & 30 & 38.5 \\
\hline $30-39$ thn & 37 & 47.4 \\
\hline $40-49$ thn & 10 & 12.8 \\
\hline$>50$ thn & 1 & 1.3 \\
\hline \multicolumn{3}{|l|}{ Kepemilikan rumah } \\
\hline $\begin{array}{r}\text { Milik sendiri/ } \\
\text { keluarga }\end{array}$ & 66 & 84.6 \\
\hline $\begin{array}{r}\text { Milik pemerintah/ } \\
\text { rumah dinas }\end{array}$ & 4 & 5.1 \\
\hline $\begin{array}{r}\text { Properti gereja/ } \\
\text { agama }\end{array}$ & 1 & 1.3 \\
\hline lainnya & 7 & 9.0 \\
\hline \multicolumn{3}{|l|}{ Pendidikan } \\
\hline SD & 18 & 23.1 \\
\hline SMP & 18 & 23.1 \\
\hline SMA & 25 & 32.1 \\
\hline Diploma/Univ. & 17 & 21.8 \\
\hline Tidak Sekolah & 0 & 0.0 \\
\hline
\end{tabular}

\subsection{Hubungan tingkat pendidikan ibu dan praktek seputar asuh bayi dan balita}

Tabel 2 memperlihatkan persepsi dan praktek seputar asuh balita dan bayi oleh rumah tangga anak balita stunting yang ibunya mengenyam pendidikan.

Ibu dengan tingkat pendidikan menengah ke atas cenderung lebih paham tentang usia balita yang tepat untuk diperkenalkan dengan makanan tambahan $(\mathrm{p}=0.036)$ dibandingkan ibu yang tidak sekolah atau hanya mengenyam pendidikan dasar. Ibu dengan 
tingkat pendidikan menengah ke atas juga lebih paham mengenai jenis makanan semi solid yang dapat diperkenalkan kepada bayi $(\mathrm{p}=0.047)$. Proporosi ibu dengan tingkat pendidikan menengah ke atas juga cenderung lebih paham pentingnyaASI dan makanan pendamping ASI (MPA) dibandingkan yang pendidikan dasar $(\mathrm{p}=0.011)$.

Menariknya, tidak ada perbedaan yang signifikan presentase ibu yang berpendidikan dasar terhadap ibu yang berpendidikan menengah yang secara benar merespon pertanyaan tentang sumber protein penting bagi bayi umur $6-23$ bulan $(\mathrm{p}=0.090)$. Tidak ada perbedaan yang signifikan presentase ibu yang berpendidikan dasar terhadap ibu yang berpendidikan menengah yang secara benar merespon pertanyaan tentang mempraktekan pemberian ASI eksklusif yang berlangsung selama lebih dari 2 tahun $(\mathrm{p}=0.382)$.

Temuan lainnya, tidak ada perbedaan yang signifikan presentase ibu yang berpendidikan dasar terhadap ibu yang berpendidian menengah yang secara benar merespon pertanyaan tentang memberi air putih kepada bayi berusia di bawah 6 bulan sebagai tambahan ASI di cuaca panas $(\mathrm{p}=0.750)$. Tidak ada perbedaan yang signifikan presentase ibu yang berpendidikan dasar terhadap ibu yang berpendidikan menengah yang secara benar merespon pertanyaan seriusnya situasi seorang bayi yang dinyatakan kekurang gizi atau gizi buruk $(\mathrm{p}=0.235)$

Salah satu temuan yang agak mengkhawatirkan adalah hanya sedikit responden $(17,9 \%)$ yang mampu dengan benar merespon pertanyaan tentang memberi air putih kepada bayi berusia di bawah 6 bulan sebagai tambahan ASI di cuaca panas.

Tabel 2. Persepsi dan praktek seputar asuh balita dan bayi oleh rumah tangga anak balita stunting yang ibu mengenyam pendidikan

\begin{tabular}{|c|c|c|c|c|}
\hline Variabel & $\begin{array}{c}\text { Total }(\%) \\
\mathrm{N}=78\end{array}$ & $\begin{array}{c}\text { Tidak } \\
\text { berpendidikan/ } \\
\text { pendidikan } \\
\text { dasar }\end{array}$ & $\begin{array}{l}\text { Pendidikan } \\
\text { menengah/ } \\
\text { tinggi }\end{array}$ & $\begin{array}{c}P \\
\text { value }\end{array}$ \\
\hline \multicolumn{5}{|c|}{$\begin{array}{l}\text { Proporsi Ibu yang paham usia balita } \\
\text { yang tepat untuk diperkenalkan dengan } \\
\text { makanan tambahan }\end{array}$} \\
\hline & $64(82.1)$ & $26(40.6)$ & $38(59.4)$ & 0.036 \\
\hline \multicolumn{5}{|c|}{$\begin{array}{l}\text { Proporsi Ibu yang paham jenis makanan semi solid } \\
\text { yang dapat diperkenalkan kepada bayi }\end{array}$} \\
\hline & $60(76.9)$ & $24(40.0)$ & $38(59.4)$ & 0.047 \\
\hline \multicolumn{5}{|c|}{$\begin{array}{l}\text { Proporsi Ibu yang paham pentingnya ASI } \\
\text { dan makanan pendamping ASI (MPA) }\end{array}$} \\
\hline & $60(76.9)$ & $23(38.3)$ & $37(61.7)$ & 0.011 \\
\hline \multicolumn{5}{|c|}{$\begin{array}{l}\text { Proporsi Ibu yang paham sumber } \\
\text { protein penting bagi bayi umur 6-23 bulan }\end{array}$} \\
\hline & $57(73.1)$ & $23(40.4)$ & $34(59.6)$ & 0.090 \\
\hline \multicolumn{5}{|c|}{$\begin{array}{l}\text { Proporsi Ibu yang mempraktekan pemberian } \\
\text { ASI eksklusif selama lebih dari } 2 \text { tahun }\end{array}$} \\
\hline & $37(47.4)$ & $19(51.4)$ & $18(48.6)$ & 0.382 \\
\hline \multicolumn{5}{|c|}{$\begin{array}{l}\text { Dalam cuaca panas, bayi di bawah } 6 \text { bulan } \\
\text { perlu minum air putih sebagai tambahan ASI }\end{array}$} \\
\hline & $14(17.9)$ & $7(50.0)$ & $7(50.0)$ & 0.750 \\
\hline \multicolumn{5}{|c|}{$\begin{array}{l}\text { Bayi yang dinyatakan kekurangan gizi } \\
\text { atau gizi buruk adalah hal yang serius }\end{array}$} \\
\hline & $74(94.9)$ & $33(44.6)$ & $41(55.4)$ & 0.235 \\
\hline
\end{tabular}

3.3. Hubungan besaran pendapatan rumah tangga dan praktek seputar asuh bayi dan balita

Tabel 3 memperlihatkan persepsi dan praktek seputar asuh balita dan bayi oleh rumah tangga anak balita stunting yang yang besaran pemasukan lebih kecil dari Rp 500.000 per bulan dan lebih besar dari Rp 500.000 per bulan.

Tidak ada perbedaan yang signifikan presentase keluarga yangi besaran pemasukan <500rb terhadap keluarga yang besaran pemasukan $\geq 500 \mathrm{rb}$ yang secara benar merespon pertanyaan tentang usia balita yang tepat untuk diperkenalkan dengan makanan tambahan $(\mathrm{p}=0.259)$. terkait bunya mengenyam pendidikan. Tidak ada perbedaan yang signifikan presentase keluarga yangi besaran pemasukan $<500 \mathrm{rb}$ terhadap keluarga yang besaran pemasukan $\geq 500 \mathrm{rb}$ yang secara benar merespon pertanyaan tentang jenis makanan semi solidyang dapat diperkenalkan kepada bayi $(\mathrm{p}=0.532)$. Tidak ada perbedaan yang signifikan presentase keluarga yangi besaran pemasukan $<500 \mathrm{rb}$ terhadap keluarga yang besaran pemasukan $\geq 500 \mathrm{rb}$ yang secara benar merespon pertanyaan tentang pentingnya ASI dan makanan pendamping ASI (MPA) $(\mathrm{p}=0.934)$.

Menariknya, ada perbedaan yang signifikan presentase keluarga yangi besaran pemasukan $<500 \mathrm{rb}$ terhadap keluarga yang besaran pemasukan $\geq 500 \mathrm{rb}$ yang secara benar merespon pertanyaan tentang memahami sumber protein penting bagi bayi umur 623 bulan $(\mathrm{p}=0.048)$.

Tidak ada perbedaan yang signifikan presentase keluarga yangi besaran pemasukan <500rb terhadap keluarga yang besaran pemasukan $\geq 500 \mathrm{rb}$ yang secara benar merespon pertanyaan tentang pemberian ASI eksklusif selama lebih dari 2 tahun $(\mathrm{p}=0.392)$.

Tidak ada perbedaan yang signifikan presentase keluarga yangi besaran pemasukan $<500$ rb terhadap keluarga yang besaran pemasukan $\geq 500$ rb yang secara benar merespon pertanyaan tentang memberi air putih kepada bayi berusia di bawah 6 bulan sebagai tambahan ASI di cuaca panas $(\mathrm{p}=0.593)$.

Tidak ada perbedaan yang signifikan presentase keluarga yangi besaran pemasukan $<500$ rb terhadap keluarga yang besaran pemasukan $\geq 500 \mathrm{rb}$ yang secara benar merespon pertanyaan tentang seriusnya situasi seorang bayi yang dinyatakan kekurangan gizi atau gizi buruk $(\mathrm{p}=0.193)$.

Tabel 3. Persepsi dan praktek seputar asuh balita dan bayi oleh rumah tangga anak balita stunting yang besaran pemasukan lebih kecil dari 500rb dan lebih besar dari 500rb per bulan

\begin{tabular}{|c|c|c|c|c|}
\hline Variabel & $\begin{array}{c}\text { Total }(\%) \\
\mathrm{N}=78\end{array}$ & $\begin{array}{c}\text { Pendapatan } \\
<500 \mathrm{rb} \\
\mathrm{N}=33\end{array}$ & $\begin{array}{l}\text { Pendapatan } \\
\geq 500 \mathrm{rb} \\
\mathrm{N}=45\end{array}$ & $\begin{array}{c}P \\
\text { value }\end{array}$ \\
\hline \multicolumn{5}{|c|}{$\begin{array}{l}\text { Proporsi Ibu yang paham usia balita } \\
\text { yang tepat untuk diperkenalkan dengan } \\
\text { makanan tambahan }\end{array}$} \\
\hline & $64(82.1)$ & $26(40.6)$ & $38(59.4)$ & 0.259 \\
\hline \multicolumn{5}{|c|}{$\begin{array}{l}\text { Proporsi Ibu yang paham jenis makanan semi solid } \\
\text { yang dapat diperkenalkan kepada bayi }\end{array}$} \\
\hline & $60(76.9)$ & $25(41.7)$ & $35(58.3)$ & 0.532 \\
\hline
\end{tabular}




\begin{tabular}{|c|c|c|c|}
\hline \multicolumn{4}{|c|}{$\begin{array}{l}\text { Proporsi Ibu yang paham pentingnya ASI } \\
\text { dan makanan pendamping ASI (MPA) }\end{array}$} \\
\hline $60(76.9)$ & $26(43.3)$ & $34(56.7)$ & 0.934 \\
\hline \multicolumn{4}{|c|}{$\begin{array}{l}\text { Proporsi Ibu yang paham sumber } \\
\text { protein penting bagi bayi umur 6-23 bulan }\end{array}$} \\
\hline $57(73.1)$ & $21(36.8)$ & $36(63.2)$ & 0.048 \\
\hline \multicolumn{4}{|c|}{ Proporsi Ibu yang mempraktekan pemberian } \\
\hline \multicolumn{4}{|c|}{ ASI eksklusif selama lebih dari 2 tahun } \\
\hline $37(47.4)$ & $18(48.6)$ & $19(51.4)$ & 0.392 \\
\hline \multicolumn{4}{|c|}{$\begin{array}{l}\text { Dalam cuaca panas, bayi di bawah } 6 \text { bulan } \\
\text { perlu minum air putih sebagai tambahan ASI }\end{array}$} \\
\hline 14(17.9) & $7(50.0)$ & $7(50.0)$ & 0.593 \\
\hline \multicolumn{4}{|c|}{$\begin{array}{l}\text { Bayi yang dinyatakan kekurangan gizi } \\
\text { atau gizi buruk adalah hal yang serius }\end{array}$} \\
\hline $74(94.9)$ & $31(41.9)$ & $43(58.1)$ & 0.193 \\
\hline
\end{tabular}

\section{Kesimpulan}

Studi ini mengkonfirmasi bahwa tingkat pendidikan ibu menjadi salah faktor yang berpengaruh terhadap persepsi dan praktek seputar asuh balita di antara rumah tangga yang mempunyai anak balita stunting. Dengan kata lain, setiap usaha meningkatkan pendidikan ibu juga berdampak pada persepsi dan praktek seputar asuh balita.

Sebagai implikasi untuk praktek, studi ini menyarankan peningkatan akses kepada pendidikan bagi kaum wanita sebagai salah satu bentuk intervensi nyata penanganan stunting. Intervensi pada area pendidikan justru akan berdampak lebih nyata terhadap usaha menekan angka stunting di kabupaten Manggarai.

\section{Ucapan Terima Kasih (Acknowledgments)}

Terima kasih peneliti ucapkan kepada Badan Perencanaan Pembangunan Penelitian dan Pengembangan Daerah yang telah mendanai penelitian. Secara khusus Peneliti menyampaikan terima kasih kepada Aprianus Ronny Paskal Modena yang menjadi rekan diskusi utama untuk memperkaya penulisan.

\section{Referensi}

Case, Anne, Lubotsky, Darren, \& Paxson, Christina. (2002). Economic status and health in childhood: The origins of the gradient. The American Economic Review, 92(5), 13081334.

Fink, Gunther, Victora, Cesar G., Harttgen, Kenneth, Vollmer, Sebastian, Vidaletti, Luís Paulo, \& Barros, Aluisio J. D. (2017). Measuring Socioeconomic Inequalities With Predicted Absolute Incomes Rather Than Wealth Quintiles: A Comparative Assessment Using Child Stunting Data From National Surveys. American Journal of Public Health, 107, 550-555. doi: doi:10.2105/AJPH.2017.303657

Habimana, Samuel, \& Biracyaza, Emmanuel. (2019). Risk Factors Of Stunting Among Children Under 5 Years Of Age In The Eastern And
Western Provinces Of Rwanda: Analysis Of Rwanda Demographic And Health Survey 2014/2015. Pediatric Health, Medicine and Therapeutics, 10, 115-130.

Jurkowski, Janine M., Mills, Lisa L. Green, Lawson, Hal A., Bovenzi, Mari C., Quartimon, Ronald, \& Davison, Kirsten K. (2013). Engaging low-income parents in childhood obesity prevention from start to finish: A case study. J Community Health, 38, 1-11. doi: DOI 10.1007/s10900-012-9573-9

Lloyd, Simon J., Bangalore, Mook, Chalabi, Zaid, Kovats, R. Sari, Hallegatte, Stèphane, Rozenberg, Julie, . . . Havlík, Petr. (2018). A Global-Level Model of the Potential Impacts of Climate Change on Child Stunting via Income and Food Price in 2030. Environmental Health Perspectives, 126(9), 1-15.

Mendez, Nina, Barrera-Pérez, Mario, Palma-Solis, Marco, Zavala-Castro, Jorge, Dickinson, Federico, Azcorra, Hugo, \& Prelip, Michael. (2016). Ethnicity and income impaact on BMI and stature of school children livin in urban Southern Mexico. J. Biosoc. Sci., 48, 143-157. doi: doi:10.1017/S0021932015000127

Monteiro, Carlos Augusto, Benicio, Maria Helena D’Aquino, Conde, Wolney Lisboa, Konno, Silvia, Lovadino, Ana Lucia, Barros, Aluisio JD, \& Victora, Cesar Gomes. (2010). Narrowing socioeconomic inequality in child stunting: the Brazilian experience, 1974-2007. Bull World Health Organ, 88, 305-311. doi: doi:10.2471/BLT.09.069195

Poel, Ellen Van de, Hosseinpoor, Ahmad Reza, Speybroeck, Niko, Ourti, Tom Van, \& Vega, Jeanette. (2008). Socioeconomic inequality in malnutrition in developing countries. Bulletin of the World Health Organization, 86(4), 282-291. doi: doi:10.2471/BLT.07.044800

Schmeer, Kammi K. (2010). Household income during childhood and young adult weight status: Evidence from a nutrition transition setting. Journal of Health and Social Behavior, 51(1), 79-91.

Seguin, Louise, Xu, Qian, Potvin, Louise, Zunzunegui, Maria-Victoria, \& Frohlich, Katherine L. (2003). Effects of low income on infant health. Canadian Medical Association Journal, 168(12), 1533-1538.

Semba, Richard D., Pee, Saskia de, Sun, Kai, Sari, Mayang, Akhter, Nasima, \& Bloem, Martin W. (2008). Effect of parental formal education on risk of child stunting in Indonesia and Bangladesh: a cross-sectional study. The Lancet, 371, 322-328. 
Sharaf, Mesbah Fathy, Mansour, Elhussien Ibrahim, \& Rashad, Ahmed Shoukry. (2019). Child nutritional status in egypt: A comprehensive analysis of socioeconomic determinants using a quantile regression approach. $J$. Biosoc. Sci., 51, 1-17. doi: doi:10.1017/S0021932017000633

Stobaugh, Heather C., Rogers, Beatrice L., Webb, Patrick, Rosenberg, Irwin H., Thakwalakwa, Chrissie, Maleta, Kenneth M., . . . Manary, Mark J. (2018). Household-level factors associated with relapse following discharge from treatment for moderate acute malnutrition. British Journal of Nutrition, 119, 1039-1046. doi: doi:10.1017/S0007114518000363

Sunguya, Bruno F, Ong, Ken IC, Dhakal, Sumi, Mlunde, Linda B, Shibanuma, Akira, Yasuoka, Junko, \& Jimba, Masamine. (2014). Strong nutrition governance is a key to addressing nutrition transition in low and middle-income countries: review of countries' nutrition policies. Nutrition Journal, 13(65), 1-10. doi: doi:10.1186/1475-2891-13-65

Wang, Anqi, Scherpbier, Robert W., Huang, Xiaona, Guo, Sufang, Yang, Yuning, JosephsSpaulding, Jonathan, . . . Wang, Yan. (2017). The dietary diversity and stunting prevalence in minority children under 3 years old: a cross-sectional study in fortytwo counties of Western China. British Journal of Nutrition, 118, 840-848. doi: doi:10.1017/S0007114517002720 